\title{
Dual-Laboratory Validation of a Method for the Determination of Fructans in Infant Formula and Adult Nutritionals: First Action 2016.14
}

\author{
KOMMER BRUNT \\ Rotating Disc BV, 9753 HV Haren, The Netherlands \\ Peter Sanders \\ Eurofins Carbohydrate Competence Centre, 8440 AT Heerenveen, The Netherlands \\ VÉRONIQUE SPICHTIG \\ Nestlé Research Centre, 1000 Lausanne, Switzerland \\ Veronica ERnSTe-Nota \\ Eurofins Carbohydrate Competence Centre, 8440 AT Heerenveen, The Netherlands \\ Paulina Sawicka \\ East Scotland College, Aberdeen, AB25 1BN, United Kingdom \\ KimberLey IWANOFF \\ Nestlé Quality Assurance Centre, York, United Kingdom \\ Jeroen VAN Soest \\ Eurofins Carbohydrate Competence Centre, 8440 AT Heerenveen, The Netherlands \\ Paul Kong Thoo Lin \\ Robert Gordon University, Aberdeen, AB10 7AQ, United Kingdom \\ Sean Austin ${ }^{1}$ \\ Nestlé Research Centre, 1000 Lausanne, Switzerland
}

Nestlé Research Centre, 1000 Lausanne, Switzerland; Robert Gordon University, Aberdeen, AB10 7AQ, United Kingdom; North

\section{Stakeholder Panel on INFANT Formula AND ADULT NUTRITIONALS}

\section{EXPERT REVIEW PANEL FOR NUTRIENT METHODS}

Darryl Sullivan, Chair, Covance Labs

John Austad, Covance Labs

Sneh Bhandari, Silliker Labs

Esther Campos-Gimenez, Nestlé

Scott Christiansen Perrigo

Hans Cruijsen, FrieslandCampina

Jon DeVries, General Mills/Medallion Labs

Brendon Gill, Fonterra

Don Gilliland, Abbott Nutrition

Min Huang, Frontage Labs

Estela Kneeteman, INTI

Adrienne McMahon, Nestlé

Bill Mindak, FDA

Maria Ofitserova, Pickering Lab

Melissa Phillips, NIST

Shay Phillips, Mead Johnson

Karen Schimpf, Abbott Nutrition

Guenther Raffler, CLF-Eurofins

Kate Rimmer, NIST

Wil van Loon, FrieslandCampina

Jinchuan Yang, Waters Corp.

\footnotetext{
Submitted for publication January 2017.

Adopted as a First Action Official Method by the Expert Review

Panel for Nutrient Methods

${ }^{1}$ Corresponding author's e-mail: sean.austin@rdls.nestle.com

DOI: 10.5740/jaoacint.2016_14
}

AOAC Official Method 2016.14

Fructans in Infant Formula and Adult Nutritionals HPAEC-PAD

First Action 2016

\section{A. Principle}

Samples are reconstituted in water (if required) and further diluted until the concentration of fructan in solution is such that after hydrolysis, the fructose and glucose concentration is within the range covered by the standard curve. The diluted sample is treated with a mixture of sucrase and $\alpha$-glucanases to hydrolyze sucrose and $\alpha$-glucans, respectively, releasing their constituent monosaccharides. The sample is passed through an SPE cartridge packed with graphitized carbon. Salts and monosaccharides pass through and are washed away, while the fructans are retained. Fructans are released from the column using an acetonitrile solution. The released fructans are hydrolyzed with an inulinase mixture, and the released glucose and fructose are analyzed by highperformance anion-exchange chromatography (HPAEC) with pulsed amperometric detection (PAD). The fructan content is calculated by summing the glucose and $0.9 \times$ the fructose content measured. In some matrixes containing low amounts of fructans, a blank correction may be necessary and can be applied. In this study, blank corrections were required only at the lowest fructan concentration $(0.03 \mathrm{~g} / 100 \mathrm{~g})$ and only for a few products. For unknown matrixes containing fructan concentrations below $0.1 \mathrm{~g} / 100 \mathrm{~g}$, it is advisable to check whether the blank correction is required. 


\section{B. Materials}

Samples from the SPIFAN II SLV Kit were provided by Covance (Madison, WI) and are listed in Table 2016.14A. In addition, two infant formulas from Nestlé (Vevey, Switzerland) were included in the SLV performed at NRC. Fructan ingredients used for spiking experiments were Orafti ${ }^{\circledR}$ P95 and Orafti HP (both from Beneo, Tienen, Belgium) and NutraFlora ${ }^{\circledR}$ P-95 (Ingredion, Inc., Westchester, IL).

The samples were stored in the original package in a dry place and protected from light until the moment of use. According to the instructions for this SLV Kit and the AOAC Standard Method Performance Requirements (SMPRs ${ }^{\circledR}$ ) defined in SMPR 2014.002 (5), all powder products except SRM 1849a were reconstituted by dissolving $25 \mathrm{~g}$ powder in $200 \mathrm{~g}$ water. The SRM 1849a was weighed directly or reconstituted by dissolving $10 \mathrm{~g}$ in $90 \mathrm{~g}$ water.

In this validation study, three different standards of pure fructan ingredients were used:

(1) Orafti HP, a long-chain inulin ingredient.

(2) Orafti P95, a hydrolyzed inulin ingredient consisting of both GFn and Fm constituents.

(3) NutraFlora P-95, a short-chain FOS based on enzymatic sucrose elongation, mainly consisting of GF2, GF3, and GF4 constituents.

The purity of these standards was established by analysis according to Method 997.08 (3).

\section{Apparatus}

(a) Analytical balance.-Weighing to $\pm 0.1 \mathrm{mg}$ (MettlerToledo, Greifensee, Switzerland).

(b) $\mathrm{pH}$ Meter.--Reading $0.1 \mathrm{pH}$ (Metrohm, Herisau, Switzerland).

(c) Microtubes. - $2 \mathrm{~mL}$ (Eppendrof, Hamburg, Germany).

(d) Water bath. $-80 \pm 1{ }^{\circ} \mathrm{C}$ (Thermo Fisher Scientific, Waltham, MA).

(e) Water bath. $-40 \pm 1{ }^{\circ} \mathrm{C}$ (Thermo Fisher Scientific).

(f) Centrifuge.-For $2 \mathrm{~mL}$ microtubes able to operate at $10000 \times g$ (Eppendorf).

(g) Micropipets with tips $(0.1-1 \mathrm{~mL})$.- Socorex IsbA S.A. (Ecublens, Switzerland).

(h) Vortex mixer.- Scientific Industries (Bohemia, NY).

(i) Single-use plastic pipets, 5 and $10 \mathrm{~mL}$.-Becton, Dickinson \& Co. (Franklin Lakes, NJ).

(j) Single-use syringes, $2 \mathrm{~mL}$.-Becton, Dickinson \& Co.

(k) Syringe membrane filters, nylon, $0.2 \mu \mathrm{m}$, Ø $13 \mathrm{~mm}$.Teknokrama (Barcelona, Spain).

(I) Graphitized carbon (100 mg) SPE columns.-SigmaAldrich (St. Louis, MO).

(m) Membrane filter nylon, $0.2 \mu \mathrm{m}, \varnothing 4.7 \mathrm{~cm}$ Merck-Millipore (Merck KGaA, Darmstadt, Germany).

(n) Analytical column.-CarboPac PA20 (150 × $3 \mathrm{~mm}$, $6.5 \mu \mathrm{m})$ or CarboPac PA1 $(250 \times 2 \mu \mathrm{mm}, 10 \mu \mathrm{m})$ with guard $(50 \times 2 \mathrm{~mm}, 10 \mu \mathrm{m}$; Thermo Fisher Scientific).

(o) HPAEC-PAD system.-Including an eluent sparging system; gradient pump; autosampler; column compartment able to maintain a temperature of $20 \pm 0.5^{\circ} \mathrm{C}$ (for the PA1 column) or $30 \pm$ $0.5^{\circ} \mathrm{C}$ (for the PA20 column); electrochemical detector working in PAD mode; and isocratic pump for postcolumn delivery.- all Thermo Fisher Scientific.
Table 2016.14A. Contents of the SPIFAN SLV sample kit

\begin{tabular}{|c|c|c|c|c|}
\hline $\begin{array}{l}\text { Sample } \\
\text { No. }\end{array}$ & $\begin{array}{c}\text { Product } \\
\text { description }\end{array}$ & Lot No. & Matrix type & $\begin{array}{l}\text { Country of } \\
\text { origin }\end{array}$ \\
\hline \multicolumn{5}{|c|}{ Placebo products } \\
\hline 1 & $\begin{array}{l}\text { Child Formula } \\
\text { Powder }\end{array}$ & 00847RF00 & Powder & United States \\
\hline 2 & $\begin{array}{c}\text { Infant Elemental } \\
\text { Powder }\end{array}$ & 00796RF & Powder & United States \\
\hline 3 & $\begin{array}{l}\text { Adult Nutritional } \\
\text { RTF, High-Protein }\end{array}$ & 00821RF00 & Liquid & United States \\
\hline 4 & $\begin{array}{l}\text { Adult Nutritional } \\
\text { RTF, High-Fat }\end{array}$ & 00820RF00 & Liquid & United States \\
\hline 5 & $\begin{array}{l}\text { Infant Formula } \\
\text { RTF, Milk-Based }\end{array}$ & $\mathrm{EV} 4 \mathrm{H} 2 \mathrm{Q}$ & Liquid & United States \\
\hline \multicolumn{5}{|c|}{ Fortified products } \\
\hline 6 & SRM 1849a & CLC10-b & Powder & United States \\
\hline 7 & $\begin{array}{l}\text { Infant Formula } \\
\text { Powder, Partially } \\
\text { Hydrolyzed } \\
\text { Milk-Based }\end{array}$ & $410057652 Z$ & Powder & United States \\
\hline 8 & $\begin{array}{l}\text { Infant Formula } \\
\text { Powder, Partially } \\
\text { Hydrolyzed } \\
\text { Soy-Based }\end{array}$ & $410457651 Z$ & Powder & United States \\
\hline 9 & $\begin{array}{c}\text { Toddler Formula } \\
\text { Powder, } \\
\text { Milk-Based }\end{array}$ & 4052755861 & Powder & Ireland \\
\hline 10 & $\begin{array}{l}\text { Infant Formula } \\
\text { Powder, } \\
\text { Milk-Based }\end{array}$ & 4044755861 & Powder & Ireland \\
\hline 11 & $\begin{array}{l}\text { Adult Nutritional } \\
\text { Powder, Low-Fat }\end{array}$ & 0859RF00 & Powder & United States \\
\hline 12 & $\begin{array}{l}\text { Child Formula } \\
\text { Powder }\end{array}$ & 00866RF00 & Powder & United States \\
\hline 13 & $\begin{array}{c}\text { Infant Elemental } \\
\text { Powder }\end{array}$ & 00795RF & Powder & United States \\
\hline 14 & $\begin{array}{l}\text { Infant Formula } \\
\text { Powder, FOS/ } \\
\text { GOS-Based }\end{array}$ & $50350017 W 1$ & Powder & Switzerland \\
\hline 15 & $\begin{array}{l}\text { Infant Formula } \\
\text { Powder, } \\
\text { Milk-Based }\end{array}$ & K16NTAV & Powder & United States \\
\hline 16 & $\begin{array}{c}\text { Infant Formula } \\
\text { Powder, } \\
\text { Soy-Based }\end{array}$ & E10NWZC & Powder & United States \\
\hline 17 & $\begin{array}{l}\text { Infant Formula } \\
\text { Powder RTF, } \\
\text { Milk-Based }\end{array}$ & EV4H2R & Liquid & United States \\
\hline 18 & $\begin{array}{l}\text { Adult Nutritional } \\
\text { RTF, High-Protein }\end{array}$ & 00730RF00 & Liquid & United States \\
\hline 19 & $\begin{array}{l}\text { Adult Nutritional } \\
\text { RTF, High-Fat }\end{array}$ & 0729RF00 & Liquid & United States \\
\hline
\end{tabular}

\section{Chemicals and Reagents}

(a) Deionized water.-18 megaohm-cm Milli-Q purified, or equivalent.

(b) Maleic acid, puriss., >99\%.-Sigma-Aldrich.

(c) Acetonitrile gradient grade for LC.-Merck-Millipore.

(d) Acetic acid glacial 100\% anhydrous, guaranteed reagent for analysis.-Merck-Millipore. 
(e) Potassium cyanohexaferrate(II) trihydrate.-Optional (Merck-Millipore).

(f) Zinc acetate.-Optional (Merck-Millipore).

(g) Trifluoroacetic acid (TFA).--Sigma-Aldrich.

(h) Hydrochloric acid, 1 M.-Merck-Millipore.

(i) Sodium acetate, anhydrous.-Sigma-Aldrich.

(j) Sodium hydroxide 50\% (w/w).-(J.T. Baker, Deventer, The Netherlands). Used for the preparation of LC eluents. To avoid production of carbonate, the bottle should be opened for the minimum time necessary to avoid exposure to air. The solution should no longer be used for eluent preparation after about twothirds of the bottle is empty (because the remaining solution will contain too much carbonate). The remaining solution can be used for other applications in the laboratory (including preparation of the solution for postcolumn addition).

(k) Sodium hydroxide pellets.-Merck-Millipore.

(l) Helium for eluent sparging.

(m) Sodium chloride.-Merck-Millipore.

(n) Sodium azide.-For use only with the PA1 column for HPAEC-PAD (Sigma-Aldrich).

(o) D-(-)-fructose, $>99 \%$.- Sigma-Aldrich.

(p) D-(+)-glucose, $\geq 99.5 \%$.-Sigma-Aldrich.

(q) Chitobiose.-Elicityl S.A. (Crolles, France).

(r) Mixture of highly purified sucrase, $\beta$-amylase, pullulanase, and maltase (from Fructan Assay Kit; K-FRUC).Megazyme (Bray, Ireland).

(s) Mixture of highly purified exo-inulinase and endo-inulinase (from $K$-FRUC).--Megazyme.

\section{E. Preparation of Reagents}

(a) Sodium maleate buffer (100 mM, pH 6.5).--Into a large beaker $(>1000 \mathrm{~mL})$, weigh $11.6 \mathrm{~g}$ maleic acid and dissolve with $900 \mathrm{~mL}$ water (using a magnetic stirrer). Adjust the $\mathrm{pH}$ to 6.5 with $1 \mathrm{M}$ sodium hydroxide solution. Transfer the solution to a $1000 \mathrm{~mL}$ volumetric flask and dilute to the mark with water. (Stored at $6 \pm 2{ }^{\circ} \mathrm{C}$, this solution is stable for 6 months.)

(b) Sodium acetate buffer (100 mM, pH 4.5).- - Into a large beaker $(>1000 \mathrm{~mL})$ containing $900 \mathrm{~mL}$ demineralized water, pipet $5.8 \mathrm{~mL}$ glacial acetic acid. Adjust to $\mathrm{pH} 4.5$ with $1 \mathrm{M}$ sodium hydroxide solution. Transfer the solution to a $1000 \mathrm{~mL}$ volumetric flask and dilute to the mark with water. (Stored at $6 \pm 2^{\circ} \mathrm{C}$, this solution is stable for 6 months.)

(c) Chitobiose solution $(600 \mu \mathrm{g} / \mathrm{mL})$. - Into a $25 \mathrm{~mL}$ volumetric flask, weigh $15 \mathrm{mg}$ chitobiose and dilute to the mark with water. (Stored at $6 \pm 2{ }^{\circ} \mathrm{C}$, this solution is stable for 1 week, or aliquot and store at $-20 \pm 2{ }^{\circ} \mathrm{C}$ for up to 12 months.)

(d) Glucose stock solution $(5 \mathrm{mg} / \mathrm{mL})$. - Into a $25 \mathrm{~mL}$ volumetric flask, weigh $125 \mathrm{mg}$ glucose and dilute to the mark with water. (Stored at $6 \pm 2^{\circ} \mathrm{C}$, this solution is stable for 1 week, or aliquot and store at $-20 \pm 2{ }^{\circ} \mathrm{C}$ for up to 12 months.)

(e) Fructose stock solution $(10 \mathrm{mg} / \mathrm{mL})$. - Into a $25 \mathrm{~mL}$ volumetric flask, weigh $250 \mathrm{mg}$ fructose and dilute to the mark with water. (Stored at $6 \pm 2{ }^{\circ} \mathrm{C}$, this solution is stable for 1 week, or aliquot and store at $-20 \pm 2{ }^{\circ} \mathrm{C}$ for up to 12 months.)

(f) Sodium hydroxide (1 M).--Dissolve $40 \pm 1 \mathrm{~g}$ sodium hydroxide pellets in $500 \mathrm{~mL}$ water in a $1000 \mathrm{~mL}$ volumetric flask. After cooling down to room temperature, dilute to the mark with demineralized water and mix well. (Stored at $22 \pm$ $5^{\circ} \mathrm{C}$, this solution is stable for 6 months).

(g) Carrez I solution.-Dissolve $106 \mathrm{~g}$ potassium hexacyanoferrate(II) trihydrate in $1000 \mathrm{~mL}$ demineralized water and store in a brown bottle (optional reagent; stored at $22 \pm 5^{\circ} \mathrm{C}$, this solution is stable for 1 month).

(h) Carrez II solution.-Dissolve $220 \mathrm{~g}$ zinc acetate in $900 \mathrm{~mL}$ demineralized water in a $1000 \mathrm{~mL}$ volumetric flask and then add $29 \mathrm{~mL}$ glacial acetic acid. Dilute to the mark with demineralized water and homogenize (optional reagent; stored at $22 \pm 5^{\circ} \mathrm{C}$, this solution is stable for 1 month).

(i) Sodium azide solution (0.5\%).-Dissolve $1 \mathrm{~g}$ sodium azide in $200 \mathrm{~mL}$ demineralized water (optional reagent needed only for the LC method on the PA1 column; stored at $22 \pm 5^{\circ} \mathrm{C}$, this solution is stable for 12 months).

(j) Sucrase/ $\beta$-amylase/pullulanase/maltase.-Dissolve the contents of the vial containing powdered sucrase, $\beta$-amylase, pullulanase, and maltase in $22.0 \mathrm{~mL}$ sodium maleate buffer (100 mM, pH 6.5). Mix well and divide into aliquots of $2.0 \mathrm{~mL}$ each and store frozen at $-20^{\circ} \mathrm{C}$ in polypropylene tubes until use. (Stored at $-20 \pm 2^{\circ} \mathrm{C}$, this solution is stable for 12 months.) Note: For the development and validation of this method, the preprepared enzyme mixture available in the Megazyme kit, K-FRUC, was used. When enzymes from another source are used, it is imperative to ensure that the enzyme mixture will completely hydrolyze any sucrose in the product without hydrolyzing the fructan. This can be checked by performing an analysis with sucrose as an analyte and with a pure fructan as an analyte. No fructan should be measured when sucrose is analyzed, and $>90 \%$ recovery should be achieved when a pure fructan is analyzed.

(k) Fructanase (exo-inulinase/endo-inulinase).-Dissolve the contents of the vial containing powdered exo-inulinase and endo-inulinase in $22.0 \mathrm{~mL}$ sodium acetate buffer $(100 \mathrm{mM}$, $\mathrm{pH}$ 4.5). Mix well and divide into aliquots of $2.0 \mathrm{~mL}$ each and store frozen at $-20^{\circ} \mathrm{C}$ in polypropylene tubes until use. (Stored at $-20 \pm 2{ }^{\circ} \mathrm{C}$, this solution is stable for 12 months.) Note: For the development and validation of this method, the preprepared enzyme mixture available in the Megazyme kit, K-FRUC, was used. When enzymes from another source are used, it is imperative to ensure that the enzyme mixture used will completely hydrolyze the fructan without hydrolyzing any other glucose- or fructose-containing oligo- or polysaccharide that may be present after treatment with the sucrase mixture in $\mathbf{E}(\mathbf{j})$.

(I) Wash solution for graphitized carbon column, 0.1\% TFA$80 \%$ acetonitrile $(\mathrm{v} / \mathrm{v})$. - - Into a $100 \mathrm{~mL}$ volumetric flask, add $80 \mathrm{~mL}$ acetonitrile (HPLC grade) and $100 \mu \mathrm{L}$ TFA. Dilute to the mark with water. (Stored at $22 \pm 5^{\circ} \mathrm{C}$, this solution is stable for 6 months.)

(m) Sodium chloride solution (1 M) for graphitized carbon column.-Into a $100 \mathrm{~mL}$ volumetric flask, weigh $5.8 \mathrm{~g}$ sodium chloride and dissolve with $90 \mathrm{~mL}$ demineralized water. Dilute to the mark with water. (Stored at $22 \pm 5^{\circ} \mathrm{C}$, this solution is stable for 6 months.)

(n) Elute solution for graphitized carbon column, $0.05 \%$ TFA-25\% acetonitrile $(v / v)$. - Into a $100 \mathrm{~mL}$ volumetric flask, add $25 \mathrm{~mL}$ acetonitrile (HPLC grade) and $50 \mu \mathrm{L}$ TFA. Dilute to the mark with water. (Stored at $22 \pm 5^{\circ} \mathrm{C}$, this solution is stable for 6 months.) 


\section{F. Mobile Phase Preparation (Using CarboPac PA 20) Performed at NRC}

(a) Eluent A for PA20 column: $300 \mathrm{mM}$ sodium hydroxide solution.-Into an HPLC bottle, introduce $985 \mathrm{~mL}$ deionized water, and degas with helium for $20 \mathrm{~min}$. Add $15.6 \mathrm{~mL}$ sodium hydroxide solution (50\%). Degas with helium for $20 \mathrm{~min}$ and keep under a blanket of helium until, and during, use. (Stored at $22 \pm 5^{\circ} \mathrm{C}$ under a blanket of helium, this solution is stable for 1 week.)

(b) Eluent B for PA20 column: Milli- $Q$ water.-Into an HPLC bottle, introduce $2000 \mathrm{~mL}$ water, and degas with helium for $20 \mathrm{~min}$. Thereafter, keep under a blanket of helium until, and during, use. (Stored at $22 \pm 5^{\circ} \mathrm{C}$ under a blanket of helium, this solution is stable for 2 days.)

(c) Eluent $C$ for PA20 column: $500 \mathrm{mM}$ sodium acetate-150 mM sodium hydroxide solution.-Into a $1000 \mathrm{~mL}$ volumetric flask, weigh $41.0 \mathrm{~g}$ anhydrous sodium acetate and dissolve with $800 \mathrm{~mL}$ water by mixing. Dilute to the mark with water, and filter on a $0.20 \mu \mathrm{m}$ nylon membrane filter into an HPLC bottle. Degas with helium for $20 \mathrm{~min}$ and then add (using a single-use plastic pipet) $7.8 \mathrm{~mL} 50 \%(\mathrm{w} / \mathrm{w}) \mathrm{NaOH}$ solution. Swirl gently to mix, and sparge with helium for another $15 \mathrm{~min}$. Thereafter, keep under a blanket of helium until, and during, use. (Stored at $22 \pm 5^{\circ} \mathrm{C}$ under a blanket of helium, this solution is stable for 1 week.)

(d) Postcolumn addition reagent: $300 \mathrm{mM}$ sodium hydroxide.Into an HPLC bottle, introduce $985 \mathrm{~mL}$ water and add $15.6 \mathrm{~mL}$ $\mathrm{NaOH} 50 \%$ solution (using a single-use plastic pipet). Swirl the solution gently to mix. Degas with helium for $20 \mathrm{~min}$ and keep under a blanket of helium until, and during, use. (Stored at $22 \pm 5^{\circ} \mathrm{C}$, this solution is stable for 1 month.)

\section{G. Mobile Phase Preparation (Using CarboPac $P A$ 1) Performed at CCC}

(a) Eluent A for PAl column: $200 \mathrm{mM}$ sodium hydroxide solution.-Weigh $3846 \pm 5 \mathrm{~g}$ deionized water in the eluent bottle, and degas with helium for $20 \mathrm{~min}$. Add $40 \mathrm{~mL}$ sodium hydroxide solution (50\%). Degas with helium for $20 \mathrm{~min}$ and keep under a blanket of helium until, and during, use. (Stored at $22 \pm 5^{\circ} \mathrm{C}$ under a blanket of helium, this solution is stable for 1 week.)

(b) Eluent B for PA1 column: Milli- $Q$ water with sodium azide.-Fill a $4 \mathrm{~L}$ eluent bottle with $3900 \mathrm{~mL}$ carbonate-free Milli-Q water. Add $100 \mathrm{~mL} 0.5 \%$ sodium azide solution. Degas with helium for $20 \mathrm{~min}$ and keep under a blanket of helium until, and during, use. (Stored at $22 \pm 5^{\circ} \mathrm{C}$ under a blanket of helium, this solution is stable for 1 week.)

(c) LC eluent C for PA1 column: $1 M$ sodium acetate solution.-Into a $1000 \mathrm{~mL}$ volumetric flask, weigh $82.0 \mathrm{~g}$ anhydrous sodium acetate and dissolve with $800 \mathrm{~mL}$ water by mixing. Dilute to the mark with deionized water and filter on a $0.20 \mu \mathrm{m}$ nylon membrane filter into an eluent bottle. Degas with helium for $20 \mathrm{~min}$ and keep under a blanket of helium until, and during, use. (Stored at $22 \pm 5^{\circ} \mathrm{C}$ under a blanket of helium, this solution is stable for 1 week.)

(d) LC postcolumn addition reagent: $300 \mathrm{mM}$ sodium hydroxide.-Into an HPLC bottle, introduce $985 \mathrm{~mL}$ water and add $15.6 \mathrm{~mL} \mathrm{NaOH} 50 \%$ solution (using a single-use plastic pipet). Swirl the solution gently to mix. Degas with helium for 20 min and keep under a blanket of helium until, and during, use. (Stored at $22 \pm 5^{\circ} \mathrm{C}$, this solution is stable for 1 month.)

\section{H. Preparation of Standards}

Using volumetric flasks, prepare a six-level standard curve by diluting the glucose stock solution $(5 \mathrm{mg} / \mathrm{mL})$ and the fructose stock solution $(10 \mathrm{mg} / \mathrm{mL})$ to the final volume with deionized water, as described in Table 2016.14B.

Treat each of the six solutions of standards as follows: Into a microtube, transfer $200 \mu \mathrm{L}$ standard solution and add $200 \mu \mathrm{L}$ water and $100 \mu \mathrm{L}$ chitobiose internal standard solution. Next, transfer a $400 \mu \mathrm{L}$ aliquot of this solution to another microtube and add $1200 \mu \mathrm{L}$ SPE elute solution. To a $700 \mu \mathrm{L}$ aliquot of this mixture, add $300 \mu \mathrm{L}$ sodium acetate buffer. Mix well and then centrifuge at $10000 \times g$. Transfer a $900 \mu \mathrm{L}$ portion of the supernatant into a vial suitable for the instrument autosampler.

\section{Sample Preparation}

(a) For analysis of products on a ready-to-feed (RTF) basis.-Reconstitute powder or liquid concentrates according to instructions. For example, weigh $25 \mathrm{~g}$ infant formula powder into a bottle and add water $(200 \mathrm{~g})$. Mix well at room temperature, and record the final weight.

(b) For reconstituted products (as prepared above) or for products that are sold as RTF.-Weigh $9 \mathrm{~g}$ into a $50 \mathrm{~mL}$ volumetric flask and add $30 \mathrm{~mL}$ water. Confirm that the $\mathrm{pH}$ is between 5 and 9 (adapt $\mathrm{pH}$ using $1 \mathrm{M}$ hydrochloric acid or $1 \mathrm{M}$ sodium hydroxide solution, if needed) and place in a water bath at $80^{\circ} \mathrm{C}$ with constant agitation for $20 \mathrm{~min}$. After cooling, dilute to the mark with water (this is Solution A). Alternative dilutions schemes have also been applied (see Table 2016.14C).

(c) For analysis of powder products without prior reconstitution.-Weigh $1 \mathrm{~g}$ powder into a $50 \mathrm{~mL}$ volumetric flask. Add $30 \mathrm{~mL}$ water and confirm that the $\mathrm{pH}$ is between 5 and 9 (adapt $\mathrm{pH}$ using $1 \mathrm{M}$ hydrochloric acid or sodium $1 \mathrm{M}$ hydroxide solution, if needed). Heat at $80^{\circ} \mathrm{C}$ with constant agitation for $20 \mathrm{~min}$. Cool to room temperature and dilute to the mark with water (this is Solution A).

The solutions prepared above are further diluted, depending on the expected fructan content, following the guidelines in Table 2016.14C, and the resulting solution is Solution B.

Table 2016.14B. Dilution scheme for the preparation of the standard curve

\begin{tabular}{|c|c|c|c|c|c|}
\hline $\begin{array}{l}\text { Standard } \\
\text { curve } \\
\text { level }\end{array}$ & $\begin{array}{c}\text { Fructose stock } \\
\text { solution } \\
\text { vol., } \mu \mathrm{L}\end{array}$ & $\begin{array}{l}\text { Slucose stock } \\
\text { solution } \\
\text { vol., } \mu \mathrm{L}\end{array}$ & $\begin{array}{c}\text { Final } \\
\text { vol., mL }\end{array}$ & $\begin{array}{l}\text { Fructose } \\
\text { concn, } \\
\mu \mathrm{g} / \mathrm{mL}\end{array}$ & $\begin{array}{c}\text { Glucose } \\
\text { concn, } \\
\mu \mathrm{g} / \mathrm{mL}\end{array}$ \\
\hline 1 & 200 & 40 & 100 & 20 & 2 \\
\hline 2 & 400 & 200 & 20 & 200 & 50 \\
\hline 3 & 800 & 400 & 20 & 400 & 100 \\
\hline 4 & 1200 & 600 & 20 & 600 & 150 \\
\hline 5 & 1600 & 800 & 20 & 800 & 200 \\
\hline 6 & 2000 & 1000 & 20 & 1000 & 250 \\
\hline
\end{tabular}


Table 2016.14C. Possible schemes for sample dilution depending on expected fructan content

\begin{tabular}{|c|c|c|c|c|c|c|c|}
\hline \multicolumn{2}{|c|}{$\begin{array}{l}\text { Expected fructan } \\
\text { content, g/100 g }\end{array}$} & \multicolumn{3}{|c|}{$\begin{array}{l}\text { Preparation of } \\
\text { Solution } A^{a}\end{array}$} & \multicolumn{2}{|c|}{$\begin{array}{l}\text { Dilution to } \\
\text { Solution B }\end{array}$} & \multirow[b]{2}{*}{$\begin{array}{c}\text { Dilution } \\
\text { factor }\end{array}$} \\
\hline Powder & RTF & $\begin{array}{l}\text { Powder } \\
\text { weight, } g\end{array}$ & $\begin{array}{c}\text { RTF } \\
\text { weight, g }\end{array}$ & $\begin{array}{c}\text { Final } \\
\text { vol., } \mathrm{mL}\end{array}$ & $\begin{array}{c}\text { Solution A } \\
\text { vol., } m L\end{array}$ & $\begin{array}{c}\text { Final } \\
\text { vol., } \\
\text { mL }\end{array}$ & \\
\hline \multicolumn{8}{|c|}{ Used at NRC } \\
\hline$<4.5$ & $<0.5$ & 1 & 9 & 50 & $\begin{array}{l}\text { No } \\
\text { dilution }\end{array}$ & $\begin{array}{l}\text { No } \\
\text { dilution }\end{array}$ & 1 \\
\hline $4.5-9$ & $0.5-1.0$ & 1 & 9 & 50 & 5 & 10 & 2 \\
\hline $9-27$ & $1.0-3.0$ & 1 & 9 & 50 & 5 & 25 & 5 \\
\hline $27-36$ & $3.0-4.0$ & 1 & 9 & 50 & 5 & 50 & 10 \\
\hline $36-45$ & $4.0-5.0$ & 1 & 9 & 50 & 5 & 100 & 20 \\
\hline \multicolumn{8}{|c|}{ Used at CCC } \\
\hline$<1$ & $0.03-5.0$ & 4 & 4 & 100 & $\begin{array}{l}\text { No } \\
\text { dilution }\end{array}$ & $\begin{array}{c}\text { No } \\
\text { dilution }\end{array}$ & 1 \\
\hline $1-5$ & $\mathrm{NA}^{b}$ & 1 & NA & 100 & $\begin{array}{l}\text { No } \\
\text { dilution }\end{array}$ & $\begin{array}{l}\text { No } \\
\text { dilution }\end{array}$ & 1 \\
\hline $5-10$ & NA & 1 & NA & 100 & 0.1 & 0.2 & 2 \\
\hline $10-20$ & NA & 1 & NA & 100 & 1 & 5 & 5 \\
\hline $20-100$ & NA & 1 & NA & 100 & 0.25 & 5 & 20 \\
\hline
\end{tabular}

a Solution $\mathrm{A}$ is prepared by either diluting the indicated powder weight to the final volume or diluting the indicated weight of the RTF product to the final volume.

$b \quad$ NA $=$ Not Applicable.

(d) Hydrolysis of sucrose and $\alpha$-glucans.-Transfer $200 \mu \mathrm{L}$ Solution B into a $1.5 \mathrm{~mL}$ microtube and add $100 \mu \mathrm{L}$ chitobiose solution $(600 \mu \mathrm{g} / \mathrm{mL})$ and $200 \mu \mathrm{L}$ sucrose/maltase/amylase/ pullulanase enzyme mixture. Mix well and incubate at $40^{\circ} \mathrm{C}$ for $90 \mathrm{~min}$.

(e) Optional Carrez clarification.-Performed at CCC but not at NRC. Add $10 \mu \mathrm{L}$ Carrez I solution to the sample and mix well. Next, add $10 \mu \mathrm{L}$ Carrez II solution and mix again. Centrifuge at $10000 \times g$ for $10 \mathrm{~min}$, and use the supernatant for the next step.

(f) Removal of monosaccharides (CCC procedure).Prepare the graphitized carbon SPE column as follows:

(1) Flush with $3 \times 400 \mu \mathrm{L}$ wash solution.

(2) Flush with $3 \times 400 \mu \mathrm{L}$ water.

(3) Perform the following steps under gravity (i.e., without applying vacuum or positive pressure):

(a) Apply $400 \mu \mathrm{L}$ enzyme-treated solution.

(b) Wash with $1 \times 400 \mu \mathrm{L}$ sodium chloride solution (1 M).

(c) Wash with $2 \times 800 \mu \mathrm{L}$ sodium chloride solution (1 M).

(d) Wash with $5 \times 800 \mu \mathrm{L}$ water.

(e) Elute the fructans using $5 \times 400 \mu \mathrm{L}$ elute solution.

(f) Mix eluates from the SPE cartridge well.

(g) Removal of monosaccharides (NRC procedure).Prepare the graphitized carbon SPE column as follows:

(1) Flush with $3 \times 400 \mu \mathrm{L}$ wash solution.

(2) Flush with $3 \times 400 \mu \mathrm{L}$ water.

(3) Perform the following steps under gravity (i.e., without applying vacuum or positive pressure):

(a) Apply $400 \mu \mathrm{L}$ enzyme-treated solution.

(b) Wash with $2 \times 1000 \mu \mathrm{L}$ sodium chloride solution (1 M). (c) Wash with $4 \times 1000 \mu \mathrm{L}$ water.

(d) Elute the fructans into a $2 \mathrm{~mL}$ microtube using $3 \times 400 \mu \mathrm{L}$ elute solution.

(e) Apply a little positive pressure to eliminate all solution from the column.

(f) Mix eluates from the SPE cartridge well.

(h) Hydrolysis of fructans (CCC procedure).- Transfer a $1000 \mu \mathrm{L}$ portion of the eluate from the SPE cartridge into a microtube and add $350 \mu \mathrm{L}$ sodium acetate buffer $(100 \mathrm{mM}$, $\mathrm{pH} 4.5$ ) and $100 \mu \mathrm{L}$ inulinase mixture. Mix well and incubate at $40^{\circ} \mathrm{C}$ for $40 \mathrm{~min}$.

(i) Hydrolysis of fructans (NRC procedure).-To the eluate from the SPE cartridge, add $300 \mu \mathrm{L}$ sodium acetate buffer (100 mM, pH 4.5). Transfer a $700 \mu \mathrm{L}$ portion of this solution into a microtube (marked "sample") and add $100 \mu \mathrm{L}$ inulinase mixture. Into a second microtube (marked "blank"), transfer a $700 \mu \mathrm{L}$ portion of the eluate and add $100 \mu \mathrm{L}$ sodium acetate buffer $(100 \mathrm{mM}, \mathrm{pH} 4.5)$. (The blank is necessary only for some matrixes containing low amounts of fructans and may be skipped if it has already been established that it is not needed for a given matrix). For all tubes, mix well and incubate at $40^{\circ} \mathrm{C}$ for $40 \mathrm{~min}$.

(j) After cooling, centrifuge at $10000 \times g$ and then transfer a $700 \mu \mathrm{L}$ portion of the supernatant into a vial suitable for the instrument autosampler, or pass the hydrolysate through a $0.2 \mu \mathrm{m}$ syringe filter into the autosampler vial.

\section{J. Chromatographic Conditions}

(a) Using PA1 (CCC Method).- - The HPAEC-PAD system is equipped with the CarboPac PA1 guard $(2 \times 50 \mathrm{~mm}, 10 \mu \mathrm{m})$ and analytical columns $(2 \times 250 \mathrm{~mm}, 10 \mu \mathrm{m})$, or equivalent, connected in series. The columns are held at $20^{\circ} \mathrm{C}$, and the injection volume is $20 \mu \mathrm{L}$. Sodium hydroxide $(300 \mathrm{mM})$ is added postcolumn (before PAD) at a flow rate of $0.13 \mathrm{~mL} / \mathrm{min}$. Fructose and glucose are separated using the gradient described in Table 2016.14D. Carbohydrates are detected by pulsed amperometry using the quadruple waveform described in Table 2016.14E.

(b) Using PA20 (NRC Method).- - The HPAEC-PAD system is equipped with the CarboPac PA20 $(3 \times 150 \mathrm{~mm}, 6.5 \mu \mathrm{m})$ column, or equivalent. The column is held at $30^{\circ} \mathrm{C}$, and the

Table 2016.14D. HPAEC-PAD gradient for PA1 column, or equivalent

\begin{tabular}{lcccc}
\hline Time, $\min$ & Flow, $\mathrm{mL} / \mathrm{min}$ & $\mathrm{A}, \%^{a}$ & $\mathrm{~B}, \%^{b}$ & $\mathrm{C}, \%^{\mathrm{c}}$ \\
\hline 0.0 & 0.25 & 7.5 & 92.5 & 0.0 \\
13.0 & 0.25 & 7.5 & 92.5 & 0.0 \\
14.1 & 0.25 & 25.0 & 75.0 & 0.0 \\
20.0 & 0.25 & 25.0 & 75.0 & 0.0 \\
21.0 & 0.25 & 40.0 & 30.0 & 30.0 \\
28.0 & 0.25 & 40.0 & 30.0 & 30.0 \\
30.0 & 0.25 & 4.0 & 60.0 & 0.0 \\
31.0 & 0.25 & 7.5 & 92.5 & 0.0 \\
43.0 & 0.25 & 7.5 & 92.5 & 0.0 \\
\hline
\end{tabular}

a $\mathrm{A}=200 \mathrm{mM} \mathrm{NaOH}$.

b $\mathrm{B}=$ Water

c $\mathrm{C}=1 \mathrm{MNaOAC}$ 
Table 2016.14E. Quadruple waveform for carbohydrate detection

\begin{tabular}{lcc}
\hline Time, s & Voltage, $V$ & Gain region \\
\hline 0.00 & +0.10 & Off \\
0.20 & +0.10 & On \\
0.40 & +0.10 & Off \\
0.41 & -2.00 & Off \\
0.42 & -2.00 & Off \\
0.43 & +0.60 & Off \\
0.44 & -0.10 & Off \\
0.50 & -0.10 & Off \\
\hline
\end{tabular}

injection volume is $25 \mu \mathrm{L}$. Sodium hydroxide $(300 \mathrm{mM})$ is added postcolumn (before PAD) at a flow rate of $0.2 \mathrm{~mL} / \mathrm{min}$. Fructose and glucose are separated using the gradient described in Table 2016.14F. Carbohydrates are detected by pulsed amperometry using the quadruple waveform described in Table 2016.14E.

\section{K. Calibration and Calculations}

Use bracketed calibration by injecting three standards followed by 10 samples, and repeating this process (e.g., inject standards at levels 1,3 , and 5 and then 10 samples; inject standards at levels 2,4 , and 6 and then 10 samples; inject standards 1, 3, 5, etc.). For each analyte (glucose and fructose), use the instrument software to plot a six-point standard curve of (instrument response for analyte)/(instrument response for internal standard) against the concentration of the analyte in the standard. Fit a quadratic curve to the data without forcing through zero. Use the calibration curve to calculate the glucose and fructose concentration in Solution B.

Calculate the fructan concentration in the sample as follows:

$$
\begin{gathered}
\mathrm{C}_{\mathrm{G}}=\mathrm{C}_{\mathrm{GB}} \times \mathrm{D} \times(\mathrm{V} / \mathrm{m}) \times 0.0001 \\
\mathrm{C}_{\mathrm{F}}=\mathrm{C}_{\mathrm{FB}} \times \mathrm{D} \times(\mathrm{V} / \mathrm{m}) \times 0.0001 \\
\mathrm{TF}=\left(\mathrm{C}_{\mathrm{F}} \times 0.9\right)+\mathrm{C}_{\mathrm{G}}
\end{gathered}
$$

Table 2016.14F. HPAEC-PAD gradient for PA20 column, or equivalent

\begin{tabular}{lcccc}
\hline Time, $\min$ & Flow, $\mathrm{mL} / \mathrm{min}$ & $\mathrm{A}, \%^{a}$ & $\mathrm{~B}, \%^{b}$ & $\mathrm{C}, \%^{\mathrm{c}}$ \\
\hline 0.0 & 0.5 & 2 & 98 & 0 \\
17.0 & 0.5 & 2 & 98 & 0 \\
17.1 & 0.5 & 0 & 0 & 100 \\
22.0 & 0.5 & 0 & 0 & 100 \\
22.1 & 0.5 & 100 & 0 & 0 \\
27.0 & 0.5 & 100 & 0 & 0 \\
27.1 & 0.5 & 2 & 98 & 0 \\
33.0 & 0.5 & 2 & 98 & 0 \\
\hline$a$ & $\mathrm{~A}=300 \mathrm{mM} \mathrm{NaOH}$. & & & \\
$b$ & $\mathrm{~B}=$ Water. \\
$c$ & $\mathrm{C}=500 \mathrm{mM} \mathrm{NaOAc}+150 \mathrm{mM} \mathrm{NaOH}$.
\end{tabular}

where $\mathrm{C}_{\mathrm{G}}=$ the concentration of glucose $(\mathrm{g} / 100 \mathrm{~g})$ released from fructan; $\mathrm{C}_{\mathrm{GB}}=$ the concentration $(\mu \mathrm{g} / \mathrm{mL})$ of glucose in Solution B; D = the dilution factor between Solution A and Solution B (see Table 2016.14C); $\mathrm{V}=$ the total volume $(\mathrm{mL})$ of Solution $\mathrm{A} ; \mathrm{m}=$ the amount $(\mathrm{g})$ of sample weighed to prepare Solution A; $0.0001=$ the factor to convert analyte concentration in solution $(\mu \mathrm{g} / \mathrm{mL})$ to analyte concentration in sample $(\mathrm{g} / 100 \mathrm{~g}) ; \mathrm{C}_{\mathrm{F}}=$ the concentration $(\mathrm{g} / 100 \mathrm{~g})$ of fructose released from fructan; $\mathrm{C}_{\mathrm{FB}}=$ the concentration $(\mu \mathrm{g} / \mathrm{mL})$ of fructose in Solution B; $0.9=$ the factor to correct for uptake of water during fructan hydrolysis; and $\mathrm{TF}=$ the total fructan concentration $(\mathrm{g} / 100 \mathrm{~g})$ in the sample.

For samples with low fructan content requiring the blank correction, adapt the above equations as follows:

$$
\begin{gathered}
\mathrm{C}_{\mathrm{G}}=\left(\mathrm{C}_{\mathrm{GB}}-\mathrm{C}_{\mathrm{G} 0}\right) \times \mathrm{D} \times(\mathrm{V} / \mathrm{m}) \times 0.0001 \\
\mathrm{C}_{\mathrm{F}}=\left(\mathrm{C}_{\mathrm{FB}}-\mathrm{C}_{\mathrm{F} 0}\right) \times \mathrm{D} \times(\mathrm{V} / \mathrm{m}) \times 0.0001
\end{gathered}
$$

where $\mathrm{C}_{\mathrm{G} 0}=$ the concentration $(\mu \mathrm{g} / \mathrm{mL})$ of glucose in blank Solution $\mathrm{B}$; and $\mathrm{C}_{\mathrm{F} 0}=$ the concentration $(\mu \mathrm{g} / \mathrm{mL})$ of fructose in blank Solution B.

\section{Validation Design}

Table 2016.14G summarizes the main requirements described in SMPR 2014.002 (5) for the determination of fructans in infant formula and adult nutritionals. The SLVs were designed to test the method against those requirements. Reproducibility could not be assessed with only two laboratories; however, intermediate reproducibility was assessed and provided a guide as to whether the reproducibility targets might be achievable.

(a) Calibration fit.-The calibration fit was assessed at NRC by injecting calibration solutions at eight different concentrations $(2-300 \mu \mathrm{g} / \mathrm{mL}$ for glucose and $20-1100 \mu \mathrm{g} / \mathrm{mL}$ for fructose), all containing the same amount of chitobiose internal standard. Each level was prepared in triplicate. The ratio of analyte-to-chitobiose peak areas was plotted against analyte concentration, and a quadratic model was used to fit the data. The relative residuals were calculated and plotted against analyte concentration. At CCC, the same approach was taken but using 12 different concentrations $(0.051-21.78 \mu \mathrm{g} / \mathrm{mL}$ for glucose and $0.887-179 \mu \mathrm{g} / \mathrm{mL}$ for fructose).

(b) $L O D$ and LOQ.-The LOD and LOQ were assessed in slightly different ways in the two laboratories. At CCC, an infant formula containing no fructans was spiked with a low level of fructan (just above the desired LOQ of $0.03 \mathrm{~g} / 100 \mathrm{~g}$ )

Table 2016.14G. SMPRs for the determination of fructans in infant formula and adult nutritionals ${ }^{a}$

\begin{tabular}{lc}
\hline Parameter & Value \\
\hline Analytical range, g/100 g & $0.03-5.0$ \\
$\mathrm{LOQ}^{b} \mathrm{~g} / 100 \mathrm{~g}^{b}$ & $\leq 0.03$ \\
$\mathrm{RSD}_{\mathrm{r}}, \%$ & $\leq 6$ \\
$\mathrm{RSD}_{\mathrm{R}}, \%$ & $\leq 12$ \\
Recovery, \% & $90-110$
\end{tabular}

a SMPR 2014.002 (5).

$b$ Concentrations apply to the product as consumed (i.e., reconstituted powders or concentrates, or as is for RTF products). 
and analyzed 10 times (this was performed on 2 different days, with a 3-month interval in between). The SD of the results was multiplied by 3 to estimate the LOD and by 10 to estimate the LOQ. At NRC, a different infant formula was selected. It was also a blank formula, but when analyzed, minor signals at the retention times of glucose and fructose could be observed. Those signals were treated as if they actually originated from fructan, and the amount of fructan they represented was measured 14 times ( 7 days in duplicate). The LOD and LOQ were then calculated by taking the mean fructan content and adding 3 times the SD to estimate the LOD and adding 10 times the SD to estimate the LOQ.

(c) Repeatability and intermediate reproducibility.Repeatability (r) and intermediate reproducibility (iR) were assessed by analyzing samples (containing fructans) in duplicate on at least 6 different days. Excel, or the in-house statistical package Q-Stat, were used to calculate the $\mathrm{SD}(\mathrm{r})$ and $\mathrm{SD}(\mathrm{iR})$ using the following equations:

$$
\begin{gathered}
S D(r)=\sqrt{\frac{\sum_{i=1}^{n} S D_{i}^{2}}{n}}=\sqrt{\frac{\sum_{i=1}^{n}\left(x_{i 1}-x_{i 2}\right)^{2}}{2 n}} \\
S D(i R)=\sqrt{S D^{2}(b)+\frac{1}{2} \times S D^{2}(r)}
\end{gathered}
$$

where $n=$ the number of (single or duplicate) determinations; $x_{i}=$ the individual result within the set of single determinations, with $i$ going from 1 to $n ; x_{i 1}$ and $x_{i 2}=$ the two results within the set of a duplicate determination, with $i$ going from 1 to $n$; and $S D(b)=$ the SD between the means of duplicates.

(d) Recovery.--Recovery was assessed slightly differently in the two different laboratories. At NRC, several different infant formulas (containing no fructans) were spiked with three different levels of three different fructan ingredients (Table 2016.14H). The fructan content of the ingredients was separately determined following Method 997.08 (3). The spiked samples were then analyzed in duplicate on 3 different days, and the recovery was calculated by comparing the measured amount with the theoretical (expected) amount. At CCC, six samples (containing fructans) were spiked with an additional 50 or $150 \%$ of the native fructan content (using the same three different fructan ingredients; Table 2016.14I). The samples were also analyzed in duplicate on 3 different days, and the recoveries were calculated by comparing the theoretical spike amount with the measured spike amount.
Table 2016.14H. Design of spike-recovery experiment

\begin{tabular}{|c|c|c|c|c|c|}
\hline \multirow{2}{*}{$\begin{array}{l}\text { Sample } \\
\text { No. }\end{array}$} & \multirow{2}{*}{$\begin{array}{c}\text { Sample } \\
\text { description }\end{array}$} & \multicolumn{4}{|c|}{ Pure fructan ingredient } \\
\hline & & Level $0^{a}$ & Level $1^{b}$ & Level $2^{c}$ & Level $3^{d}$ \\
\hline 15 & $\begin{array}{l}\text { Infant Formula } \\
\text { Powder, } \\
\text { Milk-Based }\end{array}$ & None & Orafti P95 & Orafti HP & $\begin{array}{c}\text { NutraFlora } \\
\text { P-95 }\end{array}$ \\
\hline 16 & $\begin{array}{l}\text { Infant Formula } \\
\text { Powder, } \\
\text { Soy-Based }\end{array}$ & None & Orafti HP & $\begin{array}{l}\text { NutraFlora } \\
\text { P-95 }\end{array}$ & Orafti P95 \\
\hline 18 & $\begin{array}{l}\text { Adult Nutritional } \\
\text { RTF, High-Protein }\end{array}$ & None & $\begin{array}{c}\text { NutraFlora } \\
\text { P-95 }\end{array}$ & Orafti P95 & Orafti HP \\
\hline 11 & $\begin{array}{l}\text { Adult Nutritional } \\
\text { Powder, Low-Fat }\end{array}$ & None & Orafti P95 & Orafti HP & $\begin{array}{c}\text { NutraFlora } \\
\text { P-95 }\end{array}$ \\
\hline 7 & $\begin{array}{l}\text { Infant Formula } \\
\text { Powder, Partially } \\
\text { Hydrolyzed } \\
\text { Milk-Based }\end{array}$ & None & Orafti HP & $\begin{array}{l}\text { NutraFlora } \\
\text { P-95 }\end{array}$ & Orafti P95 \\
\hline 13 & $\begin{array}{c}\text { Infant Elemental } \\
\text { Powder }\end{array}$ & None & $\begin{array}{l}\text { NutraFlora } \\
\text { P-95 }\end{array}$ & Orafti P95 & Orafti HP \\
\hline $\bar{a}$ Leve & $0=0 \mathrm{~g} / 100 \mathrm{~g}$ & & & & \\
\hline b Leve & $1=0.03 \mathrm{~g} / 100 \mathrm{~g}$ & & & & \\
\hline${ }^{c}$ Leve & $2=2 \mathrm{~g} / 100 \mathrm{~g}$ & & & & \\
\hline${ }^{d}$ Lev & $3=5.0 \mathrm{~g} / 100 \mathrm{~g}$ & & & & \\
\hline
\end{tabular}
at NRC

Table 2016.14l. Design of spike-recovery experiment

\begin{tabular}{|c|c|c|c|c|c|}
\hline $\begin{array}{l}\text { Sample } \\
\text { No. }\end{array}$ & $\begin{array}{c}\text { Sample } \\
\text { description }\end{array}$ & $\begin{array}{l}\text { Spike } \\
\text { level }\end{array}$ & $\begin{array}{l}\text { Day 1: } \\
\text { Orafti P95 } \\
\text { spike, } \\
\text { g/100 g }\end{array}$ & $\begin{array}{c}\text { Day 2: } \\
\text { NutraFlora } \\
\text { P-95 spike, } \\
\text { g/100 g }\end{array}$ & $\begin{array}{c}\text { Day 3: } \\
\text { Orafti HP } \\
\text { spike, } \mathrm{g} / 100 \mathrm{~g}\end{array}$ \\
\hline \multirow[t]{2}{*}{1} & \multirow{2}{*}{$\begin{array}{l}\text { Child Formula } \\
\text { Powder }\end{array}$} & Low & 0.17 & 0.17 & 0.19 \\
\hline & & High & 0.49 & 0.50 & 0.53 \\
\hline \multirow[t]{2}{*}{9} & \multirow{2}{*}{$\begin{array}{c}\text { Toddler Formula } \\
\text { Powder, } \\
\text { Milk-Based }\end{array}$} & Low & 0.17 & 0.17 & 0.19 \\
\hline & & High & 0.49 & 0.50 & 0.53 \\
\hline \multirow[t]{2}{*}{10} & \multirow{2}{*}{$\begin{array}{c}\text { Infant Formula } \\
\text { Powder, } \\
\text { Milk-Based }\end{array}$} & Low & 0.17 & 0.17 & 0.19 \\
\hline & & High & 0.49 & 0.50 & 0.53 \\
\hline \multirow[t]{2}{*}{12} & \multirow{2}{*}{$\begin{array}{l}\text { Child Formula } \\
\text { Powder }\end{array}$} & Low & 0.17 & 0.17 & 0.19 \\
\hline & & High & 0.49 & 0.50 & 0.53 \\
\hline \multirow[t]{2}{*}{14} & \multirow{2}{*}{$\begin{array}{c}\text { Infant Formula } \\
\text { Powder, FOS/ } \\
\text { GOS-Based }\end{array}$} & Low & 0.017 & 0.017 & 0.019 \\
\hline & & High & 0.049 & 0.050 & 0.053 \\
\hline \multirow[t]{2}{*}{19} & \multirow{2}{*}{$\begin{array}{l}\text { Adult Nutritional } \\
\text { RTF, High-Fat }\end{array}$} & Low & 0.17 & 0.18 & 0.19 \\
\hline & & High & 0.49 & 0.50 & 0.53 \\
\hline
\end{tabular}
at CCC 